\title{
Probing the Sources of Political Order
}

\author{
Robert H. Bates \\ CID Working Paper No. 110 \\ October 2004
}

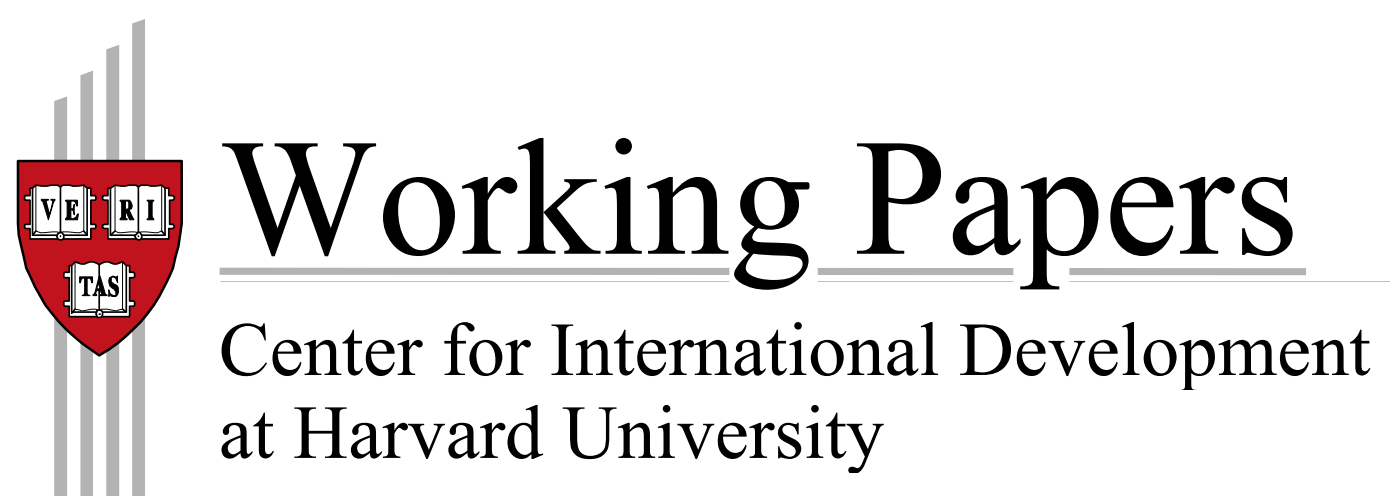




\title{
Probing the Sources of Political Order ${ }^{+}$
}

\author{
Robert H. Bates \\ Harvard University
}

\begin{abstract}
As noted by Hobbes, political order makes possible the good things of life. It constitutes the political foundations for development. Motivated by the theory of the state and qualitative materials from Africa, this paper develops a model of the foundations of political order, which it then tests on data from 46 African countries over the period 1970-1995.
\end{abstract}

Keywords: development, Africa, political economy, institutions, conflict

JEL codes: H5, O55

\footnotetext{
${ }^{+}$I wish to thank Karen Ferree, Macartan Humphreys, Smita Singh, Bela Prasad and Matt Hindman and others for help in preparing this paper. The chapter draws to a significant degree on Bates, R. H., A. Greif, et al. (2002). "Organizing Violence." Journal of Conflict Resolution 46(5): 599-628.

I also wish to thank Paul Collier, Jan Gunning, Benno Ndulu, Stephen O’Connell, Jean-Paul Azam and David Laitin for comments, plus participants in seminars at the Universities of California in Los Angeles and San Diego, ITAM, the annual meetings of the American Political Science Association and Harvard University. Financing came from the United States Institute for Peace (Grant No. USIP-02597S0) the Carnegie Foundation; the National Science Foundation (Grant No. SES-09905568); and the Weatherhead Center for International Studies and the Center for International Development, Harvard University The paper was written while a Moore Distinguished Scholar at the California Institute of Technology. I alone am responsible for the contents.
} 


\title{
Introduction
}

As stated by Hobbes, without political order

\begin{abstract}
"there is no place for industry, because the fruit thereof is uncertain; and consequently no nurture of the earth; no navigation, nor use of the commodities that may be imported by sea; no commodious buildings ...; no knowledge ... no arts; no letters .. and what is worse of all, continual fear, and danger of violent death....”(Hobbes 1961), p. 368.
\end{abstract}

To the contemporary ear, Hobbes enumeration echoes the goals of the development programs mounted by Third World governments.

Nowhere is development so deeply desired than in Africa and nowhere does political order more forcefully check its attainment. At the end of the Cold War - 19891991-Africa contained 30\% of the world's nations. Roughly $10 \%$ of the world's population resided in the continent and roughly $5 \%$ of the globe's economic product originated from it. If marked by the toppling of the Berlin wall in 1989, however, the end of the Cold War found $46 \%$ of the world's civil wars raging in Africa; if by the collapse of the Soviet Union in 1991, the number rises to 53\%. Taking civil wars as a criterion, then, Africa over-supplies state failure.

Paralleling the political performance of Africa's states runs the growth performance of Africa's economies. As demonstrated in Table 1, growth in Africa has long averaged the lowest of any region of the world. In a recent study, the World Bank 


\section{Page 3}

concludes that civil wars reduced national growth rates by 2.2 percentage points below what they would have attained had there been peace. Given the average performance of Africa's economies, the onset of a civil war is thus sufficient to render growth rates negative. 
Page 4

Table 1: Regional growth comparisons

\begin{tabular}{|c|c|c|c|c|c|c|c|c|c|c|c|c|}
\hline \multirow{4}{*}{ Region } & \multirow{4}{*}{$\mathrm{N}$} & \multicolumn{3}{|c|}{$\begin{array}{c}\text { Initial values } \\
\text { (1960 or earliest year before 1965) }\end{array}$} & \multirow{2}{*}{\multicolumn{5}{|c|}{$\begin{array}{c}\text { End-to-end annual growth rates } \\
\text { (earliest year before } 1965 \text { to latest year } \\
\text { between } 1995 \text { and 2000) } \\
\text { Real GDP }\end{array}$}} & \multicolumn{3}{|c|}{$\begin{array}{l}\text { Ending values } \\
\text { (latest year between } \\
1995 \text { and 2000) }\end{array}$} \\
\hline & & \multirow{3}{*}{$\begin{array}{l}\text { Real GDP } \\
\text { per capita } \\
\text { (1996 } \\
\text { PPP\$) }\end{array}$} & \multirow{3}{*}{$\begin{array}{l}\text { Gross } \\
\text { primary } \\
\text { enroll- } \\
\text { ment rate, } \\
1970\end{array}$} & \multirow{3}{*}{$\begin{array}{l}\text { Life } \\
\text { expec- } \\
\text { tancy } \\
\text { (years) }\end{array}$} & & & & & & \multirow{3}{*}{$\begin{array}{l}\text { Real } \\
\text { GDP per } \\
\text { capita } \\
\text { (1996 } \\
\text { PPP\$) }\end{array}$} & \multirow{3}{*}{$\begin{array}{l}\text { Gross } \\
\text { primary } \\
\text { enroll- } \\
\text { ment } \\
\text { rate }\end{array}$} & \multirow{3}{*}{$\begin{array}{l}\text { Life } \\
\text { expec- } \\
\text { tancy } \\
\text { (years) }\end{array}$} \\
\hline & & & & & \multirow[b]{2}{*}{ Total } & \multirow[b]{2}{*}{$\begin{array}{l}\text { Popula- } \\
\text { tion }\end{array}$} & \multicolumn{3}{|c|}{ Real GDP per capita } & & & \\
\hline & & & & & & & $\begin{array}{l}\text { Total } \\
(6)\end{array}$ & $\begin{array}{l}\text { Workers } \\
\text { per } \\
\text { capita } \\
(7)\end{array}$ & $\begin{array}{c}\text { Real } \\
\text { GDP per } \\
\text { worker } \\
(8)\end{array}$ & & & \\
\hline SSA & 35 & $\begin{array}{c}1263 \\
(14.1)\end{array}$ & $\begin{array}{c}53.2 \\
(52.2)\end{array}$ & $\begin{array}{c}40.9 \\
(57.9)\end{array}$ & 3.17 & 2.62 & 0.55 & -0.15 & 0.70 & $\begin{array}{l}1879 \\
(8.0)\end{array}$ & $\begin{array}{c}88.8 \\
(85.6)\end{array}$ & $\begin{array}{c}47.8 \\
(61.0)\end{array}$ \\
\hline LAC & 22 & $(37.2)$ & $\begin{array}{l}99.1 \\
(97.3)\end{array}$ & $\begin{array}{c}56.4 \\
(79.9)\end{array}$ & 3.52 & 2.08 & 1.45 & 0.42 & 1.03 & $\begin{array}{c}6032 \\
(25.7)\end{array}$ & $\begin{array}{c}113.0 \\
(109.0)\end{array}$ & $\begin{array}{r}70.8 \\
(90.4) \\
-\end{array}$ \\
\hline SASIA & 5 & $\begin{array}{c}934 \\
(10.4)\end{array}$ & $\begin{array}{l}58.6 \\
(57.5)\end{array}$ & $\begin{array}{l}45.3 \\
(64.2)\end{array}$ & 4.34 & 2.23 & 2.10 & -0.32 & 2.42 & $\begin{array}{l}2049 \\
(8.7)\end{array}$ & $\begin{array}{l}100.1 \\
(96.5)\end{array}$ & $\begin{array}{r}63.8 \\
(81.5)\end{array}$ \\
\hline EAP & 9 & $\begin{array}{l}1833 \\
(20.4)\end{array}$ & $\begin{array}{c}94.0 \\
(92.2)\end{array}$ & $\begin{array}{c}50.6 \\
(71.7)\end{array}$ & 5.52 & 2.07 & 3.45 & 0.16 & 3.29 & $\begin{array}{l}8314 \\
(35.4)\end{array}$ & $\begin{array}{l}101.3 \\
(97.7)\end{array}$ & $\begin{array}{c}69.6 \\
(88.9)\end{array}$ \\
\hline MENAT & 9 & $(31.3)$ & $\begin{array}{l}86.1 \\
(84.5)\end{array}$ & $\begin{array}{l}54.9 \\
(77.8)\end{array}$ & 4.84 & 2.04 & 2.81 & 0.16 & 2.65 & $\begin{array}{l}8251 \\
(35.1)\end{array}$ & $\begin{array}{l}104.6 \\
(100.9)\end{array}$ & $\begin{array}{l}72.0 \\
(92.0)\end{array}$ \\
\hline INDUST & 20 & 8979 & 101.9 & 70.6 & 3.40 & 0.73 & 2.67 & 0.35 & 2.32 & 23512 & 103.7 & 78.3 \\
\hline $\begin{array}{l}\text { Total } \\
\text { SSA vs S }\end{array}$ & 100 & $\begin{array}{c}3443 \\
(135.2)\end{array}$ & $\begin{array}{r}79.9 \\
(90.8)\end{array}$ & $\begin{array}{r}52.6 \\
(90.3)\end{array}$ & 3.71 & 2.00 & 1.71 & 0.12 & 1.59 & $\begin{array}{l}8280 \\
(91.7)\end{array}$ & $\begin{array}{l}100.2 \\
(88.7)\end{array}$ & $\begin{array}{r}63.9 \\
(74.9)\end{array}$ \\
\hline
\end{tabular}

Source: PWT6.1 and World Development Indicators.

Regions: SSA = Sub-Saharan Africa, LAC = Latin America and Caribbean, SASIA = South Asia, EAP = East Asia and Pacific,

MENAT $=$ Middle East, North Africa and Turkey, INDUST $=$ Industrial countries.

Notes: Except where noted, numbers in parentheses give the relevant developing-country mean as a percentage of the industrialcountry mean. The final row [*] shows the SSA mean as a percentage of the SASIA mean.

Source: O'Connell, Stephen A. (2004), "Explaining African Economic Growth: Emerging Lessons from the Growth Project," Paper presented at the AERC Plenary Session, Nairobi, May 29, 2004. [http://www.swarthmore.edu/SocSci/soconne1/aercgrth.html] 
Using a cross section of data from 31 Africa countries from 1960-1986, A. K.

Fosu (Fosu 2003) traces the channel through which political instability yields changes in aggregate output. The channel, he finds, runs through investment. As reported by van de Walle (Walle 2001), given disorder, not only do investors fail to invest; they disinvest, with as much as $40 \%$ of Africa's financial capital residing offshore (Walle 2001). It is as if Africans held too much capital, given the level of risk, and have therefore reconfigured their portfolios by moving a major portion of their holdings abroad.

Development is the creation of the possibility for the good life and political order provides its political foundation. To probe the underpinnings of development, this chapter therefore explores the roots of political disorder and does so by focusing on Africa.

\section{Background}

In addressing the sources of disorder, the concept of the state -- and thus the work of Max Weber - provide a natural point of departure. Reports from contemporary Africa provide an empirical anchor.

According to Weber, the essential property of politics - the feature that distinguishes it from economic, cultural or social life - is "physical force" (Weber 1921). The state is "a human community that successfully claims the monopoly of the legitimate use of physical force within a given territory" (Ibid.). Two features of this definition command attention: the element of coercion and the state's claim to a monopoly of it.

Many who study the advanced industrial nations find Weber's emphasis on physical force largely irrelevant to the study of politics. They focus instead on civic participation - voting or lobbying or running for office - and on the civilian branches of 
Page 6

government. But for students of Africa, Weber's position rings true and Africanists therefore place greater emphasis upon the instruments of violence and their use in politics.

Consider, for example, the prominence of the military. Using a sample of 1196 observations drawn from 46 African countries over a 26 year period (1970-1995) (see Table 2), in over a third, the armed forces provided the Head of State (see Table 3). While civilians have increasingly replaced military officers as heads of state, one need only course down the Eastern portion of the African continent to appreciate the centrality of the military in Africa's politics: the presidents of Eritrea, Ethiopia, Uganda, Rwanda -the so-called "new generation" of African leaders -- commanded the military organizations and thereby seized power. The presidents of Burundi, Zimbabwe, Mozambique and, turning North, Namibia, did so as well.

While some might dismiss this pattern as distinctive of Africa, idiosyncratic and therefore not of general significance, a glance at the history that informed Weber's vision of politics should provoke reappraisal. In Medieval Europe, the Angevines and Lancasters placed generations of warriors on the throne of England and the Merovingians and Capetians on the that of France. Throughout the Medieval and Early Modern Period, in Tilly's inimitable phrasing, "war made the state and the state made war"(Tilly 1975), p. 42. A glance at contemporary realities provides further evidence of the validity of Weber's insight: even though themselves not fighters, all heads of state stand astride a coercive apparatus: the police, the courts, the bureaucracy, and the military. As chief executives, they can cause people to be seized, detained, or sent to die in war. 
1. Angola

2. Benin

3. Botswana

4. Burkina Faso

5. Burundi

6. Cameroon

7. Cape Verde

8. Central Africa Republic

9. Chad

10. Comoros

11. Congo, Republic

12. Cote d'Ivoire

13. Djibouti

14. Equatorial Guinea

15. Ethiopia

16. Gabon

17. The Gambia

18. Ghana

19. Guinea

20. Guinea-Bissau

21. Kenya

22. Lesotho

23. Liberia
24. Madagascar

25. Malawi

26. Mali

27. Mauritania

28. Mauritius

29. Mozambique

30. Namibia

31. Niger

32. Nigeria

33. Rwanda

34. Sao Tome \& Principe

35. Senegal

36. Seychelles

37. Sierra Leone

38. Somalia

39. Sudan

40. Swaziland

41. Tanzania

42. Togo

43. Uganda

44. Democratic Republic of Congo

45. Zambia

46. Zimbabwe 


\begin{tabular}{lrrr} 
& \multicolumn{3}{c}{ Table 3: Military } \\
& Chief Executive & \\
No & Yes & \\
Time Period & 129 & 63 & 192 \\
$1970-74$ & 67.19 & 32.81 & \\
& 141 & 79 & 220 \\
$1975-79$ & 64.09 & 35.91 & \\
& 146 & 74 & 220 \\
$1980-84$ & 66.36 & 33.64 & \\
& 149 & 71 & 220 \\
$1985-89$ & 67.73 & 32.27 & \\
& 164 & 49 & 213 \\
$1990-95$ & 77.00 & 23.00 & \\
& 729 & 336 & 1065 \\
Total & 68.45 & 31.55 & \\
& &
\end{tabular}

Source: D:\Summer_Papers $\backslash$ Democratization

Weber emphasizes not only the importance of force; he also suggests that a political community becomes a state when it can successfully claim a monopoly over it. This argument too will inform the analysis. It implies that the existence of private groups who take up arms provides an appropriate indicator of political disorder. The political histories of the 46 nations in the sample over the sample period (1970-1995) yield reports of private militaries in $20 \%$ of the country-year observations in the first half of the 1970 s and in over $30 \%$ in the first half of the $1990 \mathrm{~s} .{ }^{1}$ By this criterion, roughly one quarter of the yields evidence of political disorder.

One last property of the state is of immediate relevance to this essay: its role in providing security (e.g. (Hobbes 1947)). The evidence suggests that rather than providing a source of security, to a greater degree than in other parts of the world, the state in Africa instead threatens the lives and property of its residents. Consider for

\footnotetext{
${ }^{1}$ As recorded in Keesing's Contemporary Profiles; Country Profiles of the Economist Intelligence Unit; Africa Research Bulletin; Africa Contemporary Record; and Africa South of the Sahara.
} 
Page 9

example the judgment of private investors. The International Country Risk Guide

publishes investor ratings of governments throughout the world that judge on a scale

from 1 to 10 , with 10 being the most likely and 1 the least their likelihood of repudiating

debt or of confiscating private investments. For both categories, the average ratings of

governments in Africa was significantly lower (at the 0.5 level) than those of

governments from other regions (Tables 4 and 5).

Table 4: Likelihood of Expropriation

\begin{tabular}{l|c} 
Region & Mean Rating \\
\hline Europe \& N. America & 9.48 \\
Ocean \& Australia & 9.48 \\
East. Europe \& FSSR & 7.83 \\
Central, Southern & \\
\& Eastern Asia & 7.08 \\
Latin America & 6.09 \\
N. Africa and & \\
Middle East & 6.10 \\
Sub-Saharan Africa & 5.58
\end{tabular}

Source: D:\Africa_World.log

Table 5: Likelihood of Repudiation

\begin{tabular}{l|c} 
Region & | Mean Rating \\
\hline Europe \& N. America & 9.16 \\
Oceana \& Australia & 9.00 \\
East. Europe \& FSSR & 6.22 \\
Latin America & 5.54 \\
Central, Southern & \\
\& Eastern Asia & 6.36 \\
N. Africa and Middle East & 5.39 \\
Sub-Saharan Africa & 4.68
\end{tabular}

Source: D:\Africa_World.log 
Freedom House provides comparable measures for governments' defense of political rights and civil liberties. The Freedom House indices form seven point scales (where 1 is high and 7 low). As seen in Tables 6and 7, African states join those from North Africa and the Middle East at the lower end of these ratings. Save for those from North Africa and the Middle East, the mean ratings are significantly lower for governments from Africa (at the 0.0 level) than for those from other regions.

Table 6: Political Rights

\begin{tabular}{l|c} 
Region & $\mid$ Mean Rating \\
\hline Europe \& N. America & 1.18 \\
Oceana \& Australia & 1.70 \\
Latin America & 2.97 \\
East. Europe \& FSSR & 4.45 \\
Central, Southern & \\
\& Eastern Asia & 4.87 \\
N. Africa and & \\
Middle East & 5.33 \\
Sub-Saharan Africa & 5.32 \\
\hline \multicolumn{2}{l}{ Source: D: $\backslash$ Africa_World.log }
\end{tabular}

Table 7: Civil Rights

\begin{tabular}{|c|c|}
\hline Region & Mean Rating \\
\hline Europe \& N. America & 1.45 \\
\hline Oceana \& Australia & 1.73 \\
\hline Latin America & 3.11 \\
\hline East. Europe \& FSSR & 4.54 \\
\hline Central, Southern & \\
\hline \& Eastern Asia & 4.95 \\
\hline N. Africa and & \\
\hline Middle East & 5.26 \\
\hline Sub-Saharan Africa & 5.10 \\
\hline
\end{tabular}


Students of Africa, such as Jean-Francois Bayart (Bayart 1993), speak of "the politics of the belly," while others, like Reno (Reno 2000), speak of the "shadow state": that network of economic, sociological, and political inter-relations that harness the power of the state for private purposes. As Ayittey (Ayittey 1998), declares, the "instinct" of "Africa's self-appointed leaders ... is to ... loot the national treasury, and brutally squelch all dissent" (p. 13). These characterizations underscore the import of the numerical ratings: Africa's governments often undermine rather than defend the security of their citizens.

\section{The Logic of Political Order}

This interplay between theories of the state and observations from Africa informs both the language and logic of this analysis. Heads of state as "specialists in violence." By assumption, however, they do not possess a monopoly over violence: citizens can take up arms, if inclined to do so. Political order remains problematic: it is achieved when governments refrain from predation and protect their citizens' property rights and when citizens refrain from the use of arms. Given this framework, three basic questions structure the enquiry into the sources of order:

1) Under what conditions would specialists in violence choose to employ force to defend their citizens rather than to prey upon them?

2) And under which conditions will citizens choose to disarm, leaving the government to protect their life and property?

And because neither political order nor the "Weberian state" are givens:

3) When will these choices prevail as an equilibrium? 
Having shaped the agenda of this essay, the theory of the state gives way to the theory of games. The equilibrium of a game between a specialist in violence and private citizens suggests conditions under which political order can prevail. And evidence of political disorder from Africa provides a test of the argument.

\section{The Model ${ }^{2}$}

To uncover sources of order, consider three players: G, a specialist in violence, and two citizens, $i \in\{1,2\}$. G is a specialist in violence. He is not endowed with a monopoly over it, however; the citizens too have access to arms and G can achieve a monopoly of physical force only when the citizens set theirs aside.

To be more specific, each citizen possesses a given amount of resources, denoted by $\mathrm{T}_{\mathrm{i}}$ (as in time), that she can allocate between work $\left(w_{i}\right)$, military preparedness $\left(m_{i}\right)$, and leisure $\left(l_{i}\right)$. That is,

$i \in\{1,2\}$ chooses $w_{i}, m_{i}, l_{i} \geq 0$ s.t. $w_{i}+m_{i}+m_{i} \leq \mathrm{T}_{\mathrm{i}}$.

The resources devoted to work, $w_{i}$, are productive; they result in an output of $\mathrm{F}\left(w_{i}\right)$ for player $i{ }^{3}$ Those devoted to military activity are unproductive. Rather then creating wealth, force merely redistributes it - or provides a defense against its redistribution.

After allocating their resources, each citizen observes the decision of the other; each then (sequentially) decides whether or not to attempt to raid the others' possessions. To capture this decision, define $r_{i}$ where $r_{i}=1$ if player $i$ raids and $r_{i}=0$ if she does not.

\footnotetext{
${ }^{2}$ For proofs of the claims made in this section, consult Bates, R. H., A. Greif, et al. (2002). "Organizing Violence." Journal of Conflict Resolution 46(5): 599-628.

${ }^{3} \mathrm{~F}(\bullet)$ is assumed to be a twice continuously differentiable, concave function that maps from player $i$ 's effort to her income.
} 
The amount the one can gain from raiding depends not only on the quantity of the other's assets but also on the relative strength of the players: if player $i$ attacks and player $-i$ defends, $\mathrm{M}\left(m_{i}, m_{-i}\right)$ is the share of player $-i$ 's wealth that player $i$ is able to expropriate if she allocates $m_{i}$ units of effort to perfecting her military capabilities and the other player, $-i$, allocates $m_{-i}$ units. $^{4}$

\footnotetext{
${ }^{4}$ More generally, throughout the paper we ignore the possibility that one agent eradicates the other. We maintain this assumption because we want to consider stateless societies in which there are on-going possibly violent interactions between groups -- be they tribes, communities, lineages, or villages. Similarly, we don't consider a situation in which one gain military resources by raiding the other. When this is the case, one group is likely to come to dominate the other. This is the situation we are not considering here. Alternatively, one can consider our analysis as related to a situation in which property rights are determined endogenously through interactions among the economic agents. The degree to which one can secure property rights depends upon relative coercive capabilities. See, for example, Skaperdas, S. (1992). "Cooperation, Conflict, and Power in the Absence of Property Rights." American Economic Review 82(4): 720-738.

; Grossman and Kim Grossman, H. I. (1995). The Economics of Revolutions. Providence RI, Department of Economics, Brown Universty.
}

, and Muthoo, A. (2000). On the Foundations of Property Rights, Part I: A Model of the State-of-Nature with Two Players. Tyepscript, Department of Economics. Essex, UK.

. Although the model's formulation is inspired by the historical experience of stateless societies, at the same time it ignores, for simplicity sake, potentially important aspects of conflict situations of the sort we seek to explore. It puts to the side, for example, evolutionary forces and specialization in the use of violence (as in Moselle, B. and B. Polak (1999). A Model of the Predatory State. Paper Prepared for Conference on the Breakdown of States, Princeton University. Princeton NJ.

asymmetries among the agents (as in, for example, Grossman and Kim 1995 and Muthoo, A. (2000). On the Foundations of Property Rights, Part I: A Model of the State-of-Nature with Two Players. Tyepscript, Department of Economics. Essex, UK. ; the impact of past conflicts on one's current military capabilities (discussed in Fearon, J. D. (1996). Bargaining Over Objects that Influence Future Bargaining Power. Paper Presented to the 1997 Annual Meeting of the American Political Science Association. Washington DC.

, Fearon, J. D. and D. D. Latin (1996).

"Explaining Interethnic Cooperation." American Political Science Review 90(December): 715-735.

, Laitin, D. and J. Fearon (1996).

"Explaining Interethnic Cooperation." American Political Science Review 90(4): 715-35. uncertainty and loss of potential

exchange (discussed in Skarpedas, S. (1996). Gangs and the State of Nature. The New Palgrave Dictioonary of Economics and the Law. P. Newman. London, Palgrave. and moral hazard issues (explored in Addison 2000). By the same token, this framework enables us to extend the analysis beyond that possible in other works. Specifically, it allows us to examine the endogenous determination of prosperity and violence. See the papers citied above as well as Usher, D. (1989). "The Dynasic Cycle and the Stationary State." American Economic Review 79(5): 1031-1044. 
The citizens derive their utility from income and from leisure, $U\left(I_{i}, l_{i}\right)$. They can increase their incomes by working or by employing their military capabilities to raid. Their incomes can thus be written:

$$
I_{1}=F\left(w_{1}\right)+r_{1}\left(F\left(w_{2}\right) M\left(m_{1}, m_{2}\right)-k\right)-r_{2}\left[F\left(w_{1}\right)+r_{1}\left(F\left(w_{2}\right) M\left(m_{1}, m_{2}\right)-k\right)\right] M\left(m_{2}, m_{1}\right)
$$

where $k$ is the fixed cost of raiding.

G seeks to maximize his utility, which, like that of the citizens, derives from income and leisure. As a specialist in violence, however, $\mathrm{G}$ does not need earn his income from laboring a farm or factory but from the use of force. He can increase his income by engaging in predation and seizing wealth or earn it by collecting fees for the provision of a valued service: the provision of security for those who seek to relax or to create wealth.

Three assumptions underlie the military balance between $\mathrm{G}$ and private citizens. Given that private agents are themselves capable of violence, (i) when G preys upon the economic output of a player $i, \mathrm{G}$ succeeds in capturing her wealth only in a probability, denoted by $q_{i .}$ (ii) $\mathrm{G}$ engages in predatory activity only if the expected revenues from its use of violence exceeds its costs of military activity, denoted by $\mathrm{C}_{\mathrm{G}}$, where $\mathrm{C}_{\mathrm{G}}>0$. (iii) And G can dispossess only one agent per period.

G's income therefore can be written:

$$
\begin{gathered}
I_{G}(\bullet)=\left\{\left[p_{i} q_{i i} \sum\left(F\left(w_{i}\right)+r_{i} F\left(w_{-i}\right) M\left(m_{i}, m_{-i}\right)-r_{-i} F\left(w_{i}\right) M\left(m_{-i}, m_{i}\right)\right)\left(1-t_{i i}\right)\right]+\right. \\
\left.\left[t_{i}\left(F\left(w_{i}\right)+r_{i} F\left(w_{-i}\right) M\left(m_{i}, m_{-i}\right)-r_{-i} F\left(w_{i}\right) M\left(m_{-i}, m_{i}\right)\right)\right]\right\}-C_{G}\left(p_{i}+p_{-i}\right)
\end{gathered}
$$

for $i=1,2$.

The model in Muthoo 2000 is closest to ours. While it explores the impact of asymmetries (which we do not), it does not enable agents to invest in military capabilities (as we do) or explore such issues as deterring raids by consuming leisure or the welfare implications of endogenous state. 
Should G engage in predation, then his income is depicted in the first bracketed expression. The revenue he seizes from i equals the probability of successful predation, $q i$, multiplied by player i's income from work and raiding, net the amount $i$ has paid in taxes. Should G choose to secure his income from taxes, then his income is captured by the second bracketed term, which registers the amount of taxes paid by each private agent who has chosen to do so. Note that - as indicated by the last term of the equation-- if G decides to prey upon the wealth of either agent, that is, if $p_{i}+p_{-i}>0$, then $\mathrm{G}$ has to bear the cost of the predatory activity, $\mathrm{CG}\left(p_{i}+p_{-i}\right) i>0$.

The model is thus peopled by a specialist in violence and two citizens, each seeking to maximize her utility and each endowed with the capacity to consume leisure or to secure income, if necessary by force. Within this framework, the foundations of political order reside in the conditions for an equilibrium in which the specialist chooses to refrain from predation and instead to provide security and in which the citizens refrain from taking up arms and instead engage in leisure and production.

To locate such an equilibrium, cast the interaction between $\mathrm{G}$ and the citizens as a repeated game; in such a setting, prospective losses help to define the equilibrium. The principal threat of interest in this game is that of disorder. In a state of disorder, $\mathrm{G}$ engages in predation: rather than earning his income from safeguarding the possessions of others, he instead seizes them. The citizens, for their part, stop paying taxes and rearm, either so as to raid or to defend themselves against raids by others. Because the citizens re-allocate resources from leisure and production to military activities, welfare declines. Living in disorder, people are insecure and poor. The equilibrium of this subgame we call the State Failure (SF) equilibrium. It is the possibility of a reversion to 
the payoffs of the State Failure (SF) equilibrium that constitutes the threat that promotes - or fails to promote - the decision to adhere to the choices that yield political order.

\section{Figure 1}

Equilibrium Path

Deviation From Equilibrium Path

Shadow of the Future

Discount Rate

Payoffs

\section{Political Order as an Equilibrium}

More precisely, the equilibrium conditions require that:

Each private agent chooses $w_{i}, m_{i}, l_{i}$ optimally (given the strategies of other players); refuses to raid; and pays taxes to $\mathrm{G}$, if the other agent has not raided or if $\mathrm{G}$ has refrained from seizing the wealth of a private agent. Otherwise, the private agents refuse to pay taxes and revert to self defense. 
$\mathrm{G}$ refrains from predating as long as neither private agent raids or fails to pay taxes. If either agent raids or fails to pay taxes, $\mathrm{G}$ then becomes predatory and seizes the wealth of the private agents. ${ }^{5}$

Under what conditions can political order be sustained in equilibrium? For a strategy to be an equilibrium strategy, no player should be able to gain from deviating after any history, when deviation results in a reversion to the State Failure (SF) equilibrium. That is:

I. No private agent should be able to gain by raiding or refusing to pay taxes.

II. Nor should an agent be able to gain by altering the allocation of her resources between work, leisure and military preparation.

III. G's threat to predate must be credible.

IV. And G must find it optimal not to predate if the economic agents adhere to their strategies.

While reflecting upon these conditions, focus upon G. Consider both the incentives that prevail in equilibrium and upon those that arise should a deviation occur (return to Figure 1).

G's incentives to adhere to the equilibrium choice of strategies derive from the revenues he can secure from taxation. To induce $\mathrm{G}$ to refrain from predation, the tax level, $\tau$, needs to be high enough that G finds it optimal, given the private agents' strategies, to refrain from confiscating the agents' wealth if they pay taxes. But it must also be sufficiently low that private agents prefer to purchase the services of $G$ rather than to incur the costs of providing their own security.

\footnotetext{
${ }^{5}$ Considering a similar equilibrium in which $\mathrm{G}$ punishes an agent who raided or failed to pay tax without reverting to the State Failure equilibrium does not change the analysis.
} 
The tax level must also be sufficiently low that G's threat to predate if taxes are not fully paid remains credible. Should taxes not be fully paid, G must choose between punishing and thereby triggering a reversion to the State Failure equilibrium or continuing to play the strategies that define political order. If a receipt of a portion of the revenues accrued when there is political order exceeds the payoffs under the State Failure equilibrium, G's threat to punish will not be credible. For that reason as well, taxes must not be too high.

The level of revenues that sustains political order, the model suggests, is therefore bounded both from above and below.

Adherence to the equilibrium path also depends upon G's payoffs under the State Failure (SF) equilibrium. Should the government have access to sources of income other than the payments it receives from its citizens, it may not fear the loss of tax payments that would result were it to trigger state failure. Also important is G's discount rate. Should the government place a low value on the losses that would accrue from state failure, then it would little fear the consequences that would follow an opportunistic deviation from the equilibrium path. Or should the government consider its future on the equilibrium path to be uncertain or the imperative of present action so powerful that it can pay scant regard for future consequences, then the threat of the low payoffs that accrue when in state failure would be insufficient to compel it to adhere to its choice of strategies.

The equilibrium conditions thus imply three empirical propositions:

1. That the likelihood of disorder should be related to the level of public revenues. 
2. That insofar as governments become more myopic when they face higher levels of risk, the level of political disorder should rise when their political fortunes become less certain.

3. And that governments in economies in which governments can easily confiscate valuable resources should experience higher levels of disorder than would governments in other economies.

\section{Empirical Testing}

In pondering these implications, return to African materials.

In the 1970s, Africa entered a period of economic decline. The oil price rises of 1973 and 1978 sparked a recession in the global economy, and the demand for Africa's exports shrank. Taxes on trade provide the bulk of public revenues in Africa; and with the decline in exports, government incomes atrophied. In an effort to reduce the impact of the fall in export earnings, governments borrowed from abroad. A subsequent spike in the interest rate exacerbated the costs of repayment. With reduced incomes and increased obligations, the revenues available to Africa's governments declined.

Africa's economic decline eroded its industrial base. Governments that had launched new industries now retrenched, closing plants, canceling projects, and postponing development projects. The result was a return to economies narrowly based on the export of primary products. Precious metals, gem stones, timber, and oil - the relative value of these commodities rose as national economies contracted. As reported by Collier, Elliott, et al. (2003) in their study of civil wars, "Countries with low, stagnant 


\section{Page 20}

... per capita incomes ... remain ... dependent on primary commodities for their exports face dangerously high levels of conflict" (p. 53).

Lastly, virtually all of Africa's governments came to independence under civilian governments that had achieved power in competitive elections. As seen in Table 3, however, by the 1970 s, in $33 \%$ of the country-year observations, the military governed; as seen in Table 8, non-competitive political systems - no-party or single-party systems prevailed in three-quarters. In the later $1980 \mathrm{~s}$, however, the pattern abruptly altered. The Third Wave of democratization that toppled communist governments in Eastern Europe also toppled authoritarian regimes in Africa (Bratton and van de Walle 1997).

Authoritarian governments now confronted a higher level of political risk: to retain power, they now had to compete for it.

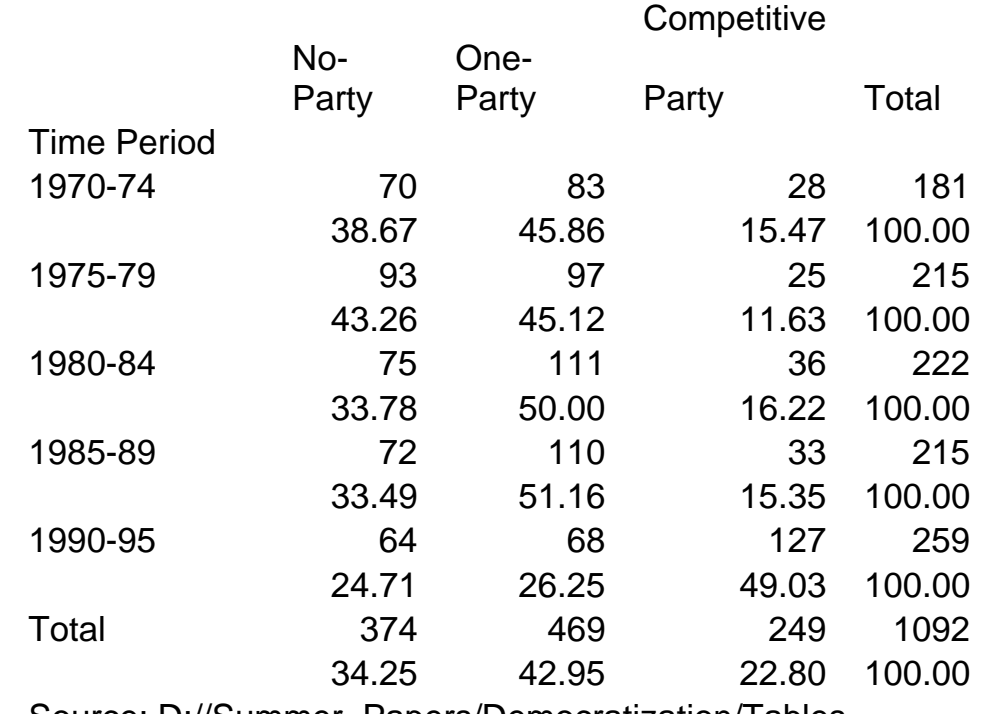

Source: D://Summer_Papers/Democratization/Tables

of Party System

Competitive

These features of the recent history of Africa -- the decline in state revenues, the increased importance of natural resources in its economies and the rise of political 


\section{Page 21}

competition- map suggestively onto the list of factors whose values determine when the choices defining political order can be sustained in equilibrium.

To be noted is that this discussion strongly echoes the work of other scholars. Collier and Hoeffler (Collier and Hanke 1998; Collier and Hoeffler 1998), Birdahl and Malone (Berdal and Malone 2000), and Reno (Reno 2000) emphasize the central role that natural resources have played in Africa's political conflicts and stressed the role of "greed" rather than "grievance" in the breakdown of states. And Eboe Hutchful (among others) stresses the problematic nature of the benefits of democratic reform in Africa: "Ironically, struggles for democracy have sometimes stimulated militarization," he writes," particularly where the conflict poses the prospect of drastic reconfiguring (sic) of political power...'((Hutchful 2000), p. 220). ${ }^{6}$

The link between resource rents and violence has also been noted by students of other regions and features in the literatures on the "resource curse" (e.g. (Ross 2003)) and the "rentier state" (e.g.(Chaudry 1994)). Chua (Chua 2003), Zakaria (Zakaria 1997) and Mansfield and Snyder (Mansfield and Snyder 1995) have highlighted the costs, rather than the benefits, of democratization in other portions of the world. The logic that underlies our analysis, then, resonates not only with the literature on Africa but also more broadly.

\section{Estimation}

The analysis thus yields propositions about the relationship between political order and three additional variables: government revenues, resource rents and political competition.

\footnotetext{
${ }^{6}$ See also the important work by Mbaku, J. M. and J. Ihonovbere, Eds. (1998). Multiparty Democracy and Political Change. Aldershot, Ashgate.
} 


\section{Page 22}

If the logic of the argument is valid, then it should yield coefficients of the proper sign, magnitude, and statistical significance.

\section{Variables}

The formation of private militias provides a measure of political order. The question asked of the data was: "For a given country in a given year: were there reports of a private military organization?"7 If the answer is "yes," then the dependent variable takes the value 1 ; if "no," the value 0 .

Dividing the central government's revenue for a given year by the Gross Domestic Product (GDP) yields a measure of public revenues. Price data and production figures collected from commercial sources and population data from the World Bank yield for each year the per capita value of the country's production of petroleum. Lastly, published sources indicate for each year ${ }^{8}$ whether the head of state presided over a noparty, one-party or competitive party system. They thereby also provide a measure of the level of political competition faced by the head of state and thus a proxy for the discount rate. Table 9 provides a list and description of the variables and the sources from which they were gathered.

\footnotetext{
${ }^{7}$ Recall the sources in footnote 2.

${ }^{8}$ Refer to the sources in footnote 2 . In coding this variable, we recorded the system in place at end of the calendar year (i.e. December 31).
} 
Table 9: Variables: Definitions, Distribution and Sources

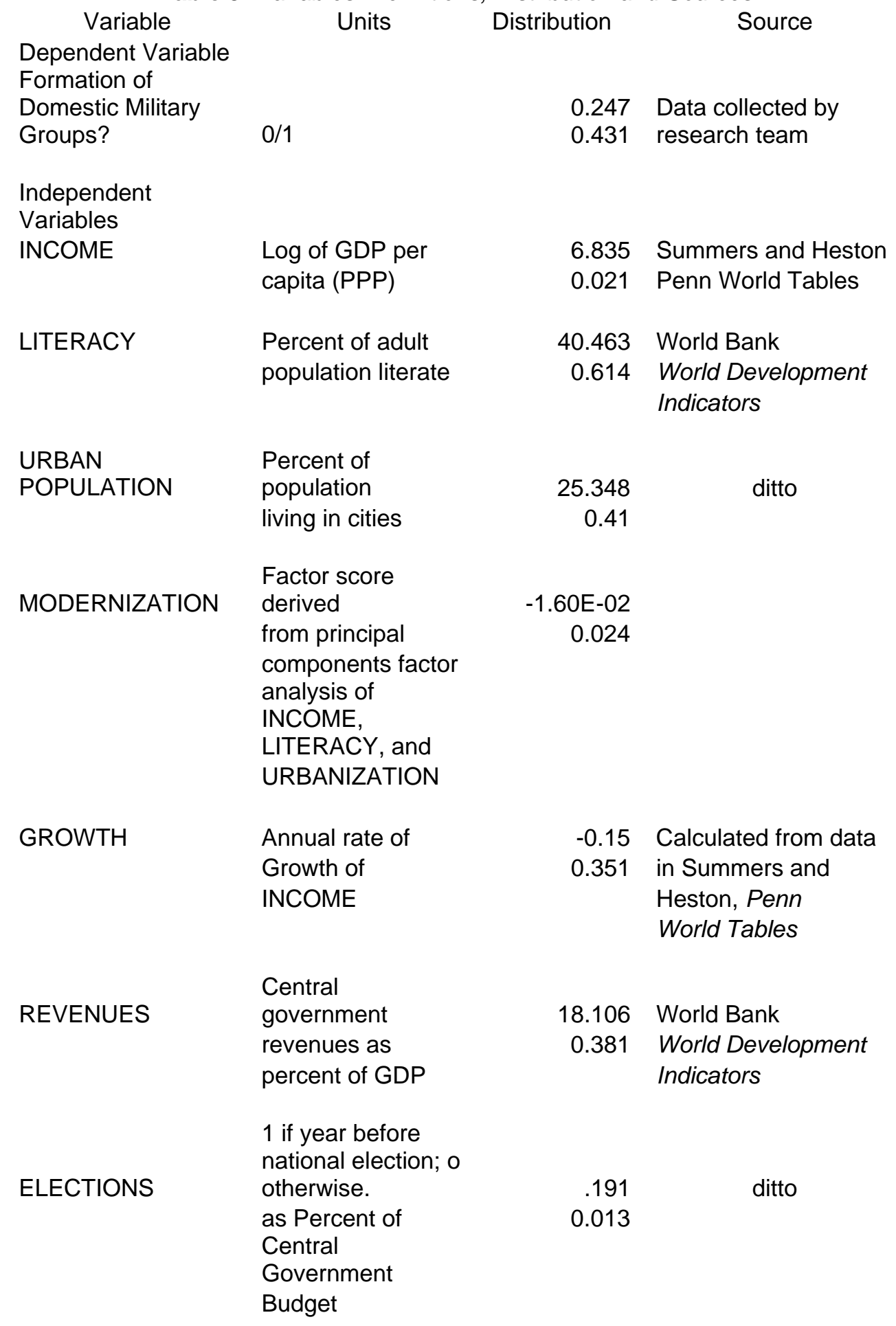


Page 24

\begin{tabular}{|c|c|c|c|}
\hline & Table 9 (Co & tinued) & \\
\hline Variable & Units & Distribution & Source \\
\hline & $\begin{array}{l}\text { Value of } \\
\text { petroleum }\end{array}$ & & \\
\hline & exports per & & \\
\hline & capita in & & \\
\hline & constant & & Data collected by \\
\hline PETROLEUM & US dollars & 81.38 & research team \\
\hline & & 14.574 & \\
\hline & $\begin{array}{l}\text { Hectares } \\
\text { of arable }\end{array}$ & & \\
\hline DROUGHT & land p.c. & .388 & \\
\hline & & 0.031 & \\
\hline DURATION & $\begin{array}{l}\text { Length of time } \\
\text { political system in } \\
\text { place }\end{array}$ & & $\begin{array}{l}\text { Data collected by } \\
\text { research team }\end{array}$ \\
\hline No-party & & 2.639 & \\
\hline & & 0.15 & \\
\hline One-Party & & 3.747 & \\
\hline & & 0.176 & \\
\hline Competitive & & 1.395 & \\
\hline & & 0.127 & \\
\hline No-party & Dummy Variable & 0.349 & ditto \\
\hline & Is 1 if Chief & 0.015 & \\
\hline & Executive & & \\
\hline & Assumes & & \\
\hline & Power Without & & \\
\hline & Facing Election & & \\
\hline One-Party & Dummy Variable & 0.444 & ditto \\
\hline & Is 1 if Chief & 0.015 & \\
\hline & Executive Elected & & \\
\hline & to Office but Faced & & \\
\hline & No Opposition & & \\
\hline & Party & & \\
\hline NEIGHBOR & Total level of & 2.728 & \\
\hline & Conflict(coups + & & \\
\hline & military groups + & & \\
\hline & civil wars) in & 0.033 & \\
\hline & Neighboring & & \\
\hline & States & & \\
\hline & Percent of & & \\
\hline & $\begin{array}{l}\text { population } \\
\text { belonging to ethnic }\end{array}$ & & \\
\hline & groups that spill & & Englebert, State \\
\hline & over national & & Legitimacy and \\
\hline CROSS & boundaries. & .733 & Development \\
\hline & & .036 & \\
\hline
\end{tabular}


The dependent variable is qualitative. Because it is bounded from above by 1 and from below by 0 , the errors from a linear model can not be identically distributed. The logistic rather than the normal distribution therefore links changes in the variables to changes in the likelihood of political disorder.

Political disorder in one country readily spills over into another; and the presence of military groups in one year can increase the likelihood of their presence in the next. , Including a measure of the total number of domestic military groups, civil wars, and international conflicts in neighboring countries helps to control for interdependence between state level observations. Entering the number of "peace years" as a variable in the equation and introducing several (three) splines helps to control for the interdependence between the annual observations (Beck, Katz et al. 1998). Robust estimation provides a further check against the impact of interdependence within and between cross-sections upon the standard errors.

Perhaps the greatest problem arises from the high level of missingness, however. ${ }^{9}$ Resorting to case-wise deletion - that is, to dropping observations which lack data for key variables - would decrease the efficiency and increase the potential for bias in the estimates; reducing the number of cases relative to the depth of the panel would introduce additional bias. We therefore employ the methods developed by Rubin ((Rubin 1996), (Schafer 1997)) to impute point estimates of the missing values and to calculate their distributions.

\footnotetext{
${ }^{9}$ This will come as no surprise to anyone who studies Africa. See Honaker, J. (2000). Issues in Multiple Imputation of Data of the African Research Program. Cambridge MA, Department of Government, Harvard University.
} 
The estimates derive from both a pooled sample and from models that include fixed effects. It is simply difficult to believe that the expected level of insecurity in, say. Botswana is the same as that in, say, Sudan, even when controlling for the impact of the variables specified by the theory.

\section{Results}

Table 9 contains definitions of the variables, reports their means and standard deviations and the sources from which they were taken.

Tables 10-13 present estimates of the core model. Tables 10-11 present data from the pooled sample; Tables 12-13, estimates that control for country-specific effects. In all instances, the country specific coefficients, taken as a group, are significant. Tables 11 and 12 contain estimates that control for potential endogeneity bias in the coefficient for government revenues; political security could, after all, be both a cause as well as a consequence of low government revenues. ${ }^{10}$

\footnotetext{
${ }^{10}$ The instruments include the lagged value of the variable, taxes on trade as a percentage of revenues, and primary products as a percentage of total exports; and the current rate of growth of the OECD countries. Entered into a fixed effects of regression, this set of instruments is significantly related to the current level of government revenues (overall $\mathrm{R}^{2}=0.89$ ) but not to the presence of domestic military groups (overall $\mathrm{R}^{2}$ $=0.007)$.
} 
Table 10: Covariates of Militarization

(Pooled Sample)

\begin{tabular}{lrrrr} 
& \multicolumn{2}{c}{ (Pooled Sample) } & & \\
& Coefficient & Std. Error & t-statistic & $\mathrm{P}>|\mathrm{t}|$ \\
Revenues & -0.099 & 0.037 & -2.696 & 0.009 \\
Revenues2 & 0.001 & 0.001 & 1.594 & 0.117 \\
No-Party & -0.742 & 0.382 & -1.941 & 0.052 \\
One-Party & -1.158 & 0.515 & -2.249 & 0.025 \\
Duration & & & & \\
No-Party & 0.112 & 0.033 & 3.431 & 0.001 \\
One-Party & 0.078 & 0.031 & 2.489 & 0.013 \\
Competitive & -0.004 & 0.043 & -0.085 & 0.932 \\
Petroleum & 0.005 & 0.005 & 0.997 & 0.319 \\
Petroleum2 & $-7.00 \mathrm{E}-06$ & $6.31 \mathrm{E}-06$ & -1.115 & 0.265 \\
Time Since & & & & \\
Last Report & -0.1839 & 0.039 & -4.73 & 0 \\
Note a: From & & & &
\end{tabular}

D://Summer_Paper/Violence/Final_Models_Core_Xsec.log

Note b: Collapsed states and non-independent states dropped from sample.

Table 11: Covariates of Militarization, With Estimated Revenues

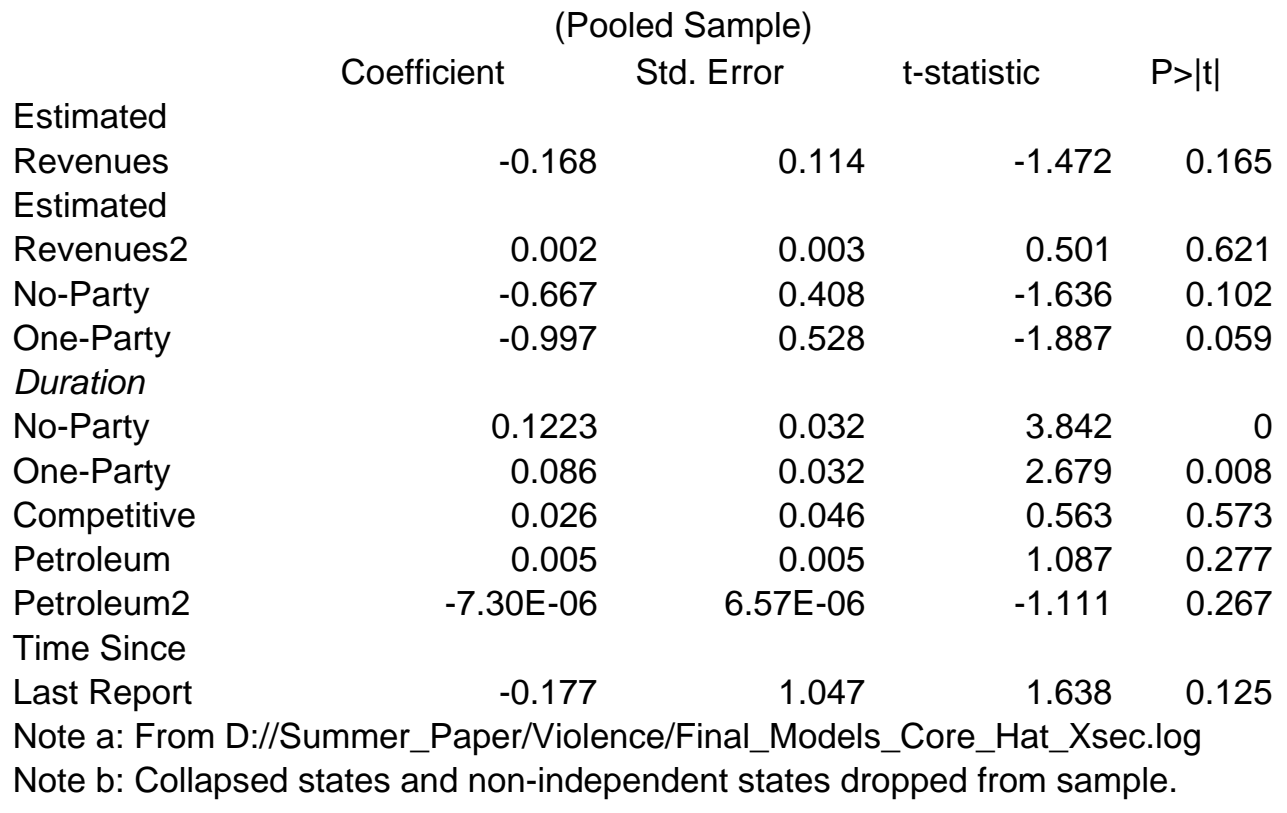


Table 12: Covariates of Militarization

(Fixed Effects)

$\begin{array}{lrrrr} & \text { Coefficient } & \text { Std. Error } & \mathrm{t} \text {-statistic } & \mathrm{P}>|\mathrm{t}| \\ \text { Revenues } & -0.044 & 0.043 & -1.015 & 0.315 \\ \text { Revenues2 } & 0.001 & 0.001 & 1.055 & 0.297 \\ \text { No-Party } & -1.196 & 0.607 & -1.972 & 0.049 \\ \text { One-Party } & -2.399 & 0.726 & -3.304 & 0.001 \\ \text { Duration } & & & & \\ \text { No-Party } & 0.014 & 0.041 & 0.344 & 0.731 \\ \text { One-Party } & 0.178 & 0.05 & 3.528 & 0 \\ \text { Competitive } & 0.085 & 0.125 & 0.677 & 0.498 \\ \text { Petroleum } & 0.015 & 0.007 & 2.018 & 0.044 \\ \text { Petroleum2 } & -1.60 E-05 & 7.01 E-06 & -2.327 & 0.02 \\ \text { Time Since } & & & & \\ \text { Last Report } & -0.016 & 0.035 & -0.461 & 0.645 \\ \text { Note a: From } & & & & \\ \text { D://Summer_Paper/Violence/Final_Models_Core_FE.log } \\ \text { Note b: Collapsed states and non-independent states dropped }\end{array}$

Note b: Collapsed states and non-independent states dropped from sample.

Table 13: Covariates of Militarization, With Estimated Revenues

\begin{tabular}{|c|c|c|c|c|}
\hline & $(\mathrm{Fi})$ & fects) & & \\
\hline & Coefficient & Error & t-statistic & $P>|t|$ \\
\hline Estimated & & & & \\
\hline Revenues & -1.536 & 0.131 & -1.164 & 0.264 \\
\hline Estimated & & & & \\
\hline Revenues2 & 0.002 & 0.003 & 0.698 & 0.49 \\
\hline No-Party & -1.162 & 0.613 & -1.895 & 0.058 \\
\hline One-Party & -2.286 & 0.734 & -3.113 & 0.002 \\
\hline Duration & & & & \\
\hline No-Party & 0.034 & 0.042 & 0.807 & 0.42 \\
\hline One-Party & 0.18 & 0.051 & 3.549 & 0 \\
\hline Competitive & 0.093 & 0.125 & 0.745 & 0.456 \\
\hline Petroleum & 0.015 & 0.007 & 2.186 & 0.029 \\
\hline Petroleum2 & $-1.60 E-05$ & $6.55 \mathrm{E}-06$ & -2.477 & 0.013 \\
\hline Time Since & & & & \\
\hline Last Report & -0.011 & 0.036 & -0.303 & 0.762 \\
\hline
\end{tabular}

Tables 14-17 repeat these estimates while including the classic set of modernization variables - INCOME, LITERACY and URBANIZATION; measures of shocks - short term GROWTH, DROUGHT, and national ELECTIONS; and the level of conflict among NEIGHBORS as well as the percentage of the nations population that 


\section{Page 29}

belong to ethnic groups that CROSS national boundaries. For present purposes, adding these variables provides a check for the robustness of the theoretical variables. In the second equation in each table, the variable MODERNIZATION replaces the measures of income, literacy, and urbanization. Based on a factor score generated from an unrotated principal components analysis of those three variables, it provides a summary measure of the level of social and economic development and a check against estimating misleading coefficients as a result of colinearity. In all of the fixed effects estimates, the country dummies remain jointly significant, even when these controls are entered into the equation.

Table 14: Covariates of Militarization

(Pooled Sample)

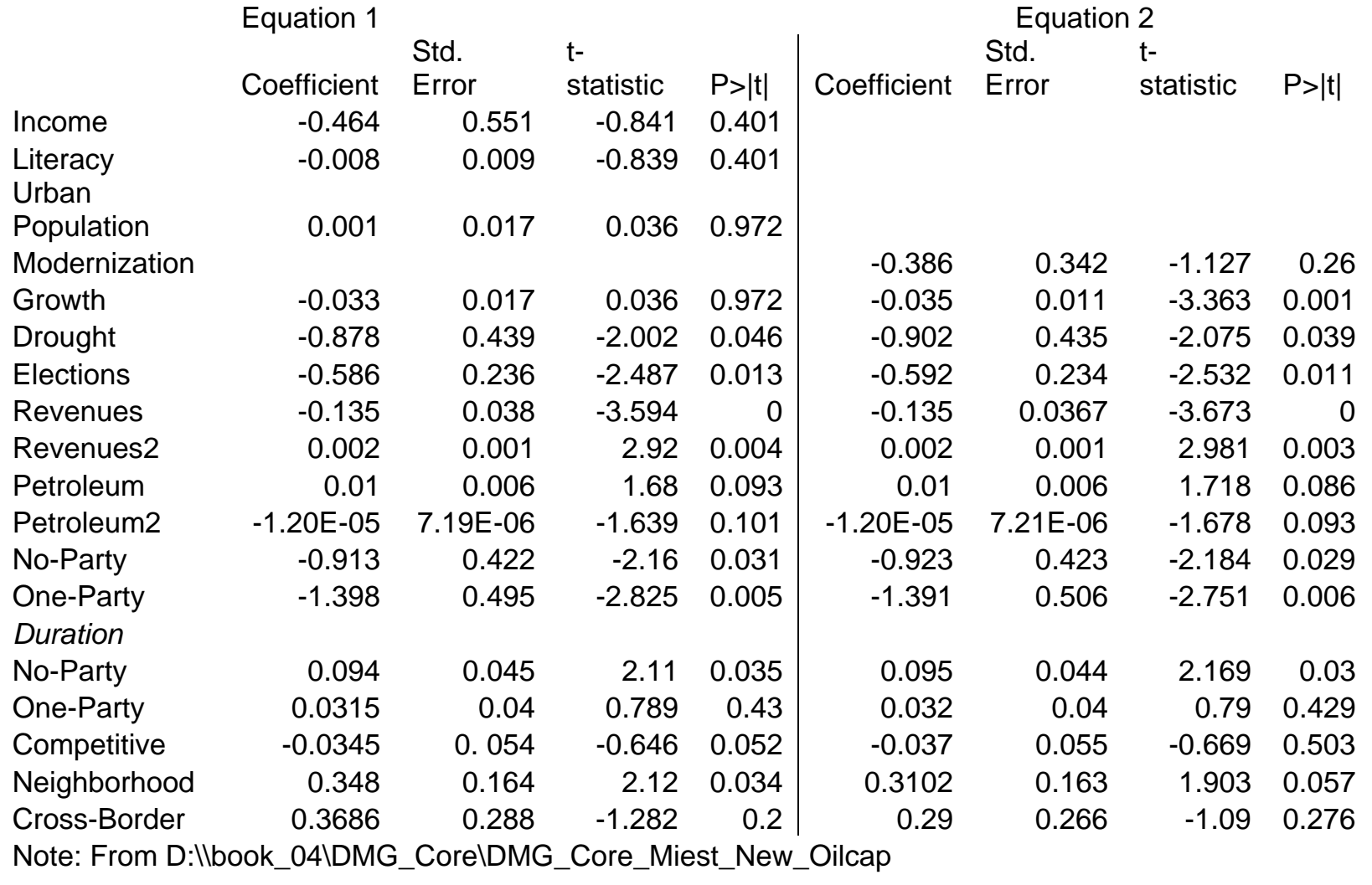


Table 15: Covariates of Militarization Using Estimated Values

\begin{tabular}{|c|c|c|c|c|c|c|c|c|}
\hline & \multicolumn{8}{|c|}{ (Pooled Sample) } \\
\hline & \multicolumn{4}{|l|}{ Equation 1} & \multicolumn{4}{|l|}{ Equation 2} \\
\hline & & Std. & $\mathrm{t}-$ & & & Std. & t- & \\
\hline & Coefficient & Error & statistic & $P>|t|$ & Coefficient & Error & statistic & $P>|t|$ \\
\hline Income & -0.497 & 0.488 & -1.019 & 0.308 & & & & \\
\hline Literacy & -0.007 & 0.009 & -0.774 & 0.439 & & & & \\
\hline Urban & & & & & & & & \\
\hline Population & 0.002 & 0.017 & 0.087 & 0.931 & & & & \\
\hline $\begin{array}{l}\text { Modernization } \\
\text { Estimated }\end{array}$ & & & & & -0.395 & 0.348 & -1.135 & 0.257 \\
\hline Growth & -0.043 & 0.068 & -0.641 & 0.522 & -0.05 & 0.07 & -0.748 & 0.455 \\
\hline Drought & -0.954 & 0.464 & -2.057 & 0.042 & -0.937 & 0.455 & -2.14 & 0.034 \\
\hline Elections & -0.521 & 0.229 & -2.271 & 0.024 & -0.524 & 0.227 & -2.308 & 0.021 \\
\hline Estimated & & & & & & & & \\
\hline Revenues & -0.285 & 0.089 & -3.202 & 0.002 &.- .283 & 0.088 & -3.217 & 0.002 \\
\hline Revenues2 & 5.00E-03 & 2.00E-03 & 2.416 & 0.017 & 0.005 & 0.002 & 2.379 & 0.018 \\
\hline Petroleum & 0.01 & 0.006 & 1.723 & 0.085 & 0.01 & 0.006 & 1.769 & 0.077 \\
\hline Petroleum2 & $-1.20 E-05$ & 7.54E-06 & 1.575 & 0.115 & $-1.20 \mathrm{E}-05$ & 7.51E-06 & 1.616 & 0.106 \\
\hline No-Party & -0.7442 & 0.43 & -1.732 & 0.083 & -0.748 & 0.436 & -1.716 & 0.086 \\
\hline One-Party & -1.362 & 0.534 & -2.542 & 0.011 & -1.359 & 0.545 & -2.489 & 0.013 \\
\hline Duration & & & & & & & & \\
\hline No-Party & 0.087 & 0.041 & 2.146 & 0.032 & 0.087 & 0.04 & 2.156 & 0.031 \\
\hline One-Party & 0.047 & 0.044 & 1.084 & 0.279 & 0.048 & 0.044 & 1.098 & 0.272 \\
\hline Competitive & -0.027 & 0.055 & -0.487 & 0.626 & -0.029 & 0.056 & -0.523 & 0.601 \\
\hline Neighborhood & 0.32 & 0.168 & 1.908 & 0.056 & 0.284 & 0.163 & 1.74 & 0.082 \\
\hline Cross-Border & -0.332 & 0.291 & -1.239 & 0.255 & -0.25 & 0.262 & -0.95 & 0.34 \\
\hline
\end{tabular}




\begin{tabular}{|c|c|c|c|c|c|c|c|c|}
\hline & \multicolumn{8}{|c|}{ (Fixed Effects) } \\
\hline & \multicolumn{4}{|l|}{ Equation 1} & \multicolumn{4}{|c|}{ Equation 2} \\
\hline & & Std. & $\mathrm{t}-$ & & & Std. & $t-$ & \\
\hline & Coefficient & Error & statistic & $P>|t|$ & Coefficient & Error & statistic & $\mathrm{P}>|\mathrm{t}|$ \\
\hline Income & 2.044 & 0.839 & 2.438 & 0.024 & & & & \\
\hline Literacy & 0.085 & 0.0381 & 2.233 & 0.026 & & & & \\
\hline \multicolumn{9}{|l|}{ Urban } \\
\hline Population & -0.052 & 0.057 & -0.916 & 0.36 & & & & \\
\hline Modernization & & & & & 2.473 & 0.905 & 2.733 & 0.007 \\
\hline Growth & -0.03 & 0.013 & -2.261 & 0.025 & -0.026 & 0.011 & -2.296 & 0.023 \\
\hline Drought & -0.185 & 0.787 & -0.235 & 0.819 & -0.161 & 0.772 & -0.208 & 0.839 \\
\hline Elections & -0.69 & 0.342 & -2.017 & 0.045 & -0.677 & 0.333 & -2.033 & 0.043 \\
\hline Revenues & -0.072 & 0.048 & -1.515 & 0.14 & -0.051 & 0.047 & -1.088 & 0.283 \\
\hline Revenues2 & 0.001 & 0.001 & 0.598 & 0.554 & 0 & 0.001 & 0.312 & 0.757 \\
\hline Petroleum & 0.015 & 0.008 & 1.894 & 0.058 & 0.013 & 0.008 & 1.561 & 0.119 \\
\hline Petroleum2 & $-1.80 E-05$ & 8.42E-06 & -2.166 & 0.03 & $-1.60 E-05$ & $9.02 \mathrm{E}-06$ & -1.803 & 0.071 \\
\hline No-Party & -6.04 & 0.603 & -1.001 & 0.317 & -0.449 & 0.536 & -0.838 & 0.402 \\
\hline One-Party & -2.016 & 0.752 & -2.683 & 0.007 & -1.789 & 0.779 & -2.297 & 0.022 \\
\hline \multicolumn{9}{|l|}{ Duration } \\
\hline No-Party & 0.018 & 0.061 & 0.292 & 0.771 & -0.009 & 0.043 & -0.215 & 0.83 \\
\hline One-Party & 0.161 & 0.053 & 3.054 & 0.002 & 0.156 & 0.048 & 3.228 & 0.001 \\
\hline Competitive & -0.007 & 0.12 & -0.059 & 0.953 & -0.002 & 0.12 & -0.019 & 0.985 \\
\hline Neighborhood & 0.09 & 0.242 & 0.0372 & 0.71 & 0.135 & 0.202 & 0.665 & 0.506 \\
\hline Cross-Border & -0.031 & 0.0466 & -0.675 & 0.5 & -0.039 & 0.041 & -0.949 & 0.343 \\
\hline \multicolumn{9}{|l|}{ Time Since } \\
\hline Last & & & & & & & & \\
\hline Observation & 0.003 & 0.036 & 0.087 & 0.931 & -0.002 & 0.038 & -0.056 & 0.956 \\
\hline
\end{tabular}

Table 16: Covariates of Militarization

\section{(Fixed Effects)}


Table 17: Covariates of Militarization Using Estimated Values

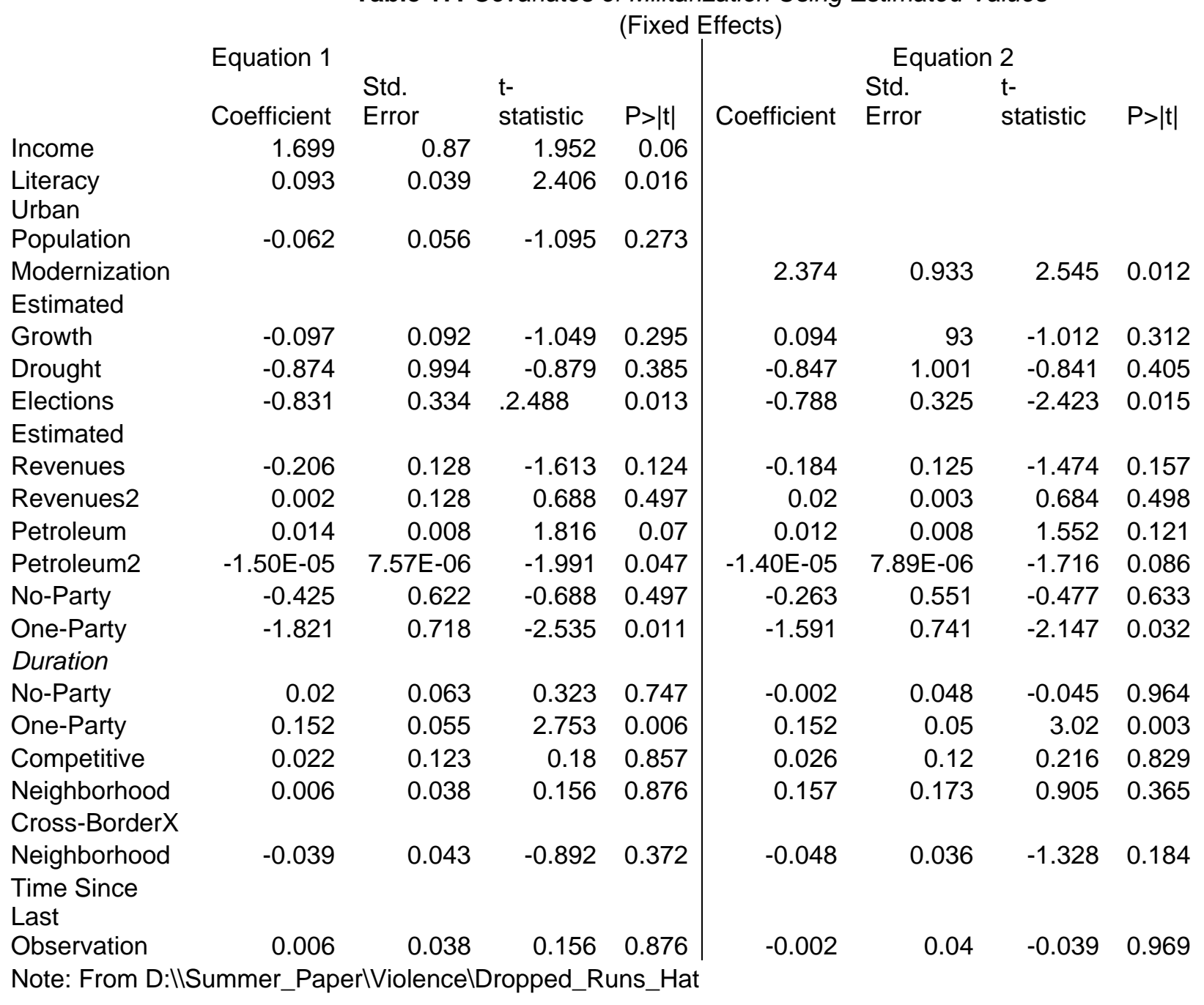

Recall that the reasoning advanced suggests that the magnitude of government

revenues should bear a negative relationship with the likelihood of civic re-armament, but that when "too high," the relationship should reverse: excessive taxation should undermine the political contract between private citizens and the state. In all instances the signs of the coefficients are as expected. While the standard errors of the coefficients estimated from the pooled sample impart confidence in the argument, those for the coefficients estimated in models that include fixed effects do not. Levels, not differences, 


\section{Page 33}

bear significant relationships with the likelihood of the formation of private militias.

Note that the coefficients for the estimated level of government revenues is greater than that of the "raw" variable, suggesting that government revenues do indeed respond negatively to increased levels of political threat. When the conventional control variables are entered into the model, the instrumented value of the revenue measure becomes statistically significant in estimates derived from the pooled sample (see Table 15).

By the logic of our argument, governments that are certain of positive economic prospects even in the midst of political disorder will be tempted to behave in ways that increase insecurity, thus increasing the likelihood of popular re-armament. The sign and significance of the coefficient on PETROLEUM lends mixed support to our reasoning, with the coefficient being significant in the fixed effects models but not in estimates drawn from the pooled sample. When controls are introduced, however, the coefficient on PETROLEUM exhibits the proper sign and attains statistical significance even when estimated in pooled samples.

It should be noted that this finding cannot be replicated for other measures: the value of diamond exports, ${ }^{11}$ the value of primary product exports, ${ }^{12}$ or the value of natural resource rents. $^{13}$

Lastly, recall the importance of the discount rate: insofar as executives have reason to fear future political chaos, they will behave in ways that enhance collective security. Should they find themselves at political risk, however, and their prospects in

\footnotetext{
${ }^{11}$ Using data collected by Macartan Humphreys.

${ }^{12}$ Using the same data as employed by Collier, P. and A. Hoeffler (1998). "On Economic Causes of Civil War." Oxford Economic Papers 50(4): 563-73.

${ }^{13}$ The value of mineral, energy and forest products as a percentage of the gross national income. Data provided by Stephen O'Connell.
} 


\section{Page 34}

office less certain, they will then place less weight on future losses and more readily succumb to present temptations.

Over the course of the sample period - 1970-1995 - the greatest challenge, perhaps, to incumbent elites came from democratic reforms. With the turn to democracy, elites that once faced no organized competition now had to face competitors for office. The level of political insecurity rose and, by our reasoning, so too the likelihood that the government would engage in predation. As seen in Tables 10-17, this implication is strongly supported by the data. In virtually every specification, the coefficients on the NO-PARTY and ONE-PARTY variables are negative and significant. As the dummy for COMPETITIVE political systems is lodged in the intercept term, the coefficients estimated from the pooled data indicate that single or no-party systems yield a higher level of political security than do competitive party systems. For their part, the coefficients in the fixed effects models indicate that moving from a no- to single-party system to a competitive party system increases the likelihood that civic society will take up arms.

An additional feature of the data merit comment: the coefficient on ELECTIONS, one of the variables introduced to control for the impact of shocks. The variable takes on the value 1 the year before a national election. In this instance, we ruled out the use of lagged values for the independent variable because we would then be excluding data from precisely the cases of greatest interest: authoritarian regimes that were adopting democratic practices. The coefficient of the variable is negative: during the run up to elections, the presence of armed groups is less frequently reported. ${ }^{14}$

\footnotetext{
${ }^{14}$ Neither contemporary nor lagged measures of national elections bore a significant relationship to the measure of political disorder.
} 
Note that when this variable is introduced into the models (Tables 14-17), the coefficients on the no- and single-party variables remain statistically significant and negative in sign; if anything, they tend increase in magnitude. Clearly the inclusion of this measure fails to reduce the impact of political competition on the likelihood of militarization. Clearly too the link between political reform and political insecurity cannot run through political campaigns. Because this finding excludes a plausible alternative explanation for the relationship between competition and conflict, it enhances the credibility of our account, which runs through the impact of competition on the conduct of the incumbent regime.

\section{Conclusion}

This chapter probes the roots of political disorder. The theory of the state and observations from contemporary Africa informed a the specification of a game theoretic model that offered insight into the conditions under which governments would use force in ways that enhance rather than weaken personal security and under which citizens would set aside arms. The Weberian state is not a given: it results when these choices form an equilibrium. Nor is state failure given, not even in Africa: it results when the level of public revenues falls, elites fear the loss of office, and those with power gain control over sources of revenues so abundant that they need not fear living in relative poverty should the state break down. 


\section{References}

Ayittey, G. B. (1998). Africa in Chaos. New York, St. Martin's Press, 1998.

Bates, R. H., A. Greif, et al. (2002). "Organizing Violence." Journal of Conflict

Resolution 46(5): 599-628.

Bayart, J. F. (1993). The State in Africa: The Politics of the Belly. New York, Longman.

Beck, N., J. N. Katz, et al. (1998). "Taking Time Series Seriously: Time-Series-CrossSection Analysis with a Binary Dependent Variable." American Journal of Political Science 42(4): 1260-88.

Berdal, M. and D. M. Malone (2000). Introduction. Greed and Grievance: Economic Agendas in Civil Wars. M. Berdal and D. Malone. Boulder CO, Lynne Rienner.

Bratton, M. and N. van de Walle (1997). Democratic Experiments in Africa. Cambridge, Cambridge University Press.

Chaudry, K. A. (1994). "Economic Liberalization and trhe Lineages of the Rentier State." Comparative Politics 27(October): 1-24.

Chua, A. (2003). World on Fire. New York, Doubleday.

Collier, P. and A. Hanke (1998). "On Economic Causes of Civil War." Oxford Economic Papers 50(4): 563-73.

Collier, P. and A. Hoeffler (1998). "On Economic Causes of Civil War." Oxford Economic Papers 50(4): 563-73.

Fearon, J. D. (1996). Bargaining Over Objects that Influence Future Bargaining Power. Paper Presented to the 1997 Annual Meeting of the American Political Science Association. Washington DC.

Fearon, J. D. and D. D. Latin (1996). "Explaining Interethnic Cooperation." American Political Science Review 90(December): 715-735.

Fosu, A. K. (2003). "Political Instability and Export Performance in Sub-Saharan Africa." The Journal of Development Economics 39(4): 68-82.

Grossman, H. I. (1995). The Economics of Revolutions. Providence RI, Department of Economics, Brown Universty.

Hobbes, T. (1947). The Leviathan. New York, E. P. Dutton. 
Hobbes, T. (1961). Leviathan. Great Political Thinkers. W. Ebenstein. New York, Holt, Reinhart and Winston.

Honaker, J. (2000). Issues in Multiple Imputation of Data of the African Research

Program. Cambridge MA, Department of Government, Harvard University.

Hutchful, E. (2000). Understanding the African Crisis. Mercenaries: An African Sucurity Dilemma. A.-F. a. J. K. Fayemi. London, Pluto Press.

Laitin, D. and J. Fearon (1996). "Explaining Interethnic Cooperation." American Political Science Review 90(4): 715-35.

Mansfield, E. and J. Snyder (1995). "Democratization and War." Foreign Affairs 74(3): 79-97.

Mbaku, J. M. and J. Ihonovbere, Eds. (1998). Multiparty Democracy and Political Change. Aldershot, Ashgate.

Moselle, B. and B. Polak (1999). A Model of the Predatory State. Paper Prepared for Conference on the Breakdown of States, Princeton University. Princeton NJ.

Muthoo, A. (2000). On the Foundations of Property Rights, Part I: A Model of the Stateof-Nature with Two Players. Tyepscript, Department of Economics. Essex, UK.

Reno, W. (2000). The real (war) economy of Angola. Angola's war Economy. J. Cilliers and C. Dietrich.

Reno, W. (2000). Shadow States and the Political Economy of Civil Wars. Greed and Grievance: Economic Agendas in Civil Wars. M. Berdal and D. Malone. Boulder CO, Lynne Riennner.

Ross, M. (2003). The Natural Resource Curse: How Wealth Can Make You Poor. Natural Resources and Violent Conflict. I. Bannon and P. Collier. Washington D.C., The World Bank.

Rubin, D. B. (1996). "Multiple Imputation after 18+ Years (with discussion)." Journal of the American Statistical Association 91: 473-489.

Schafer, J. L. (1997). Imputation of Missing Covariates in Multivariate Linear Mixed Model. University Park PA, Department of Statistics, The Pennsylvania State University.

Skaperdas, S. (1992). "Cooperation, Conflict, and Power in the Absence of Property Rights." American Economic Review 82(4): 720-738.

Skarpedas, S. (1996). Gangs and the State of Nature. The New Palgrave Dictioonary of Economics and the Law. P. Newman. London, Palgrave. 
Tilly, C. (1975). Reflections on the History of State Making. The Formation of Nation States in Western Europe. C. Tilly. Princeton, Princeton University Press.

Usher, D. (1989). "The Dynasic Cycle and the Stationary State." American Economic Review 79(5): 1031-1044.

Walle, N. v. d. (2001). African Economics and the Politics of Permanent Crisis, 19791999. New York, Cambridge University Press.

Weber, M. (1921). Politik als Beruf. Gesammelte Politische Schriften. Muenchen, Duncker \& Humblodt,

Zakaria, F. (1997). "The Rise of Illiberal Democracy." Foreign Affairs 76: 22-43. 